National Aeronautics and Space Administration

Washington. D.C. 20546

AC 202 755-8370

Joe McRoberts

Headquarters, Washington, D.C. (Phone: 202/755-3680)

RELEASE NO: $79-167$

\title{
LIFE SCIENCE INVESTIGATIONS CHOSEN FOR SPACE FLIGHTS
}

NASA has selected 78 life science areas of investigation -- 74 proposals from the United States and four from three foreign nations -- for two life science spacelab/Space Shuttle flights planned between 1983 and 1985.

Specific investigations will be selected for each mission about two years prior to flight.

The 78 were chosen from about 370 proposed experiments.

The selected investigations include the following:

- Behavior and Performance

- Bioengineering/Technology

- Plant Physiology 
- Cellular Biology, Biophysics, Biochemistry, Immunology, Virology and Microbiology

- Developmental Biology, Embryology and Gerontology

- Endocrinology, Metabolism and Nutrition

- Musculo-skeletal and Physiology

- General Physiology and Pharmacology

- Renal, Fluid and Electrolyte Physiology

- Hematology

- Cardiopulmonary and Stress Physiology

- Cardiovascular Physiology and Clinical Medicine

- Vestibular System and Neurophysiology

The 78 principal investigators are from U.S. and foreign universities, private and government organizations and the NASA scientific staff. Foreign countries involved are Australia, Switzerland and the United Kingdom. Each country is responsible for funding its own investigators.

Spacelab is a pressurized space shuttle system element designed to be operated by a payload specialist team of up to four persons. It is estimated that 15 to 20 investigations can be accommodated in each life science spacelab mission. The two missions are planned with an 18-month launch interval. The first launch is scheduled for mid-1983. A few additional Iife science investigations are expected to go on other shuttle missions during the same time period. 
The life science investigations must comply with flight safety requirements and engineering and management practices specified in NASA guidelines.

Spacelab, funded and built by the European Space Agency, will be carried to and from orbit by the Space shuttle and remain attached to the orbiter throughout each flight. Spacelab will serve as a laboratory for life science and other investigations in near-Earth orbit for a period of one week to 10 days.

With the advent of the space shuttle and availability of standard, space-qualified hardware which can be placed in orbit, repaired, retrieved or replaced, NASA plans to use this capability to reduce payload costs, while making space flight more accessible to a wider range of users.

$$
\text { \#\#\#\#\# }
$$

Note to Editors:

A list of life science investigators is attached. 
Principal Investigator

${ }^{*}$ C. D. Dunn, Ph.D. University of Tennessee,

Knoxville

D. L. Eckberg, M.D.

Virginia Commonwealth University,

Richmond

C. A. Fuller, Ph.D.

University of California,

Riverside

D. E. Parker, Ph.D.

Miami University

oxford, Ohio

Anne McLaren

University College,

London

D. G. Heathcote, Ph.D. University College of South

Wales, Cardiff, United Kingdom

R. G. Lindberg, Ph.D.

University of California,

Los Angeles

J. S. D'Arrigo, Ph.D.

University of Hawaii,

Honolulu

**Nello Pace, Ph.D.

University of California,

Berkeley

M. P. Hlastala, Ph.D.

University of Washington,

Seattle
Area of Investigation

Regulation of Erythropoiesis

Autonomic Cardiovascular

Controls

Thermoregulation in Primates

Motion Perception Evoked by Oscillating Linear

Accelerator

The Role of Gravity in Early Mammalian Development

The Influence of zero Gravity on Nutation

Stability of Biorhythms During Weightlessness

Decompression Sickness

Metabolism, Body Composition and Cardiovascular Function in Primates

Influence of Gravity on

Pulmonary Gas Exchange and

Control of Lung Function

* Three experiments in area of investigation.

**Two areas of investigation. 
L. E. Farhi, M.D.

State University of New York,

Buffalo

F. W. Booth, Ph.D.

University of Texas,

Houston

A. F. Ryan, Ph.D.

University Hospital Medical

Center, San Diego, Calif.

**R. R. Martin, M.D.

Baylor College of Medicine,

Houston

P. K. Bhagat, $\mathrm{Ph} . \mathrm{D}$.

University of Kentucky,

Lexington

R. T. Dowell, Ph.D.

University of Oklahoma,

oklahoma City

G. L. Gottlieb, Ph.D.

Rush College of Health Sciences, Chicago

P. M. Hutchins, Ph.D.

Bowman Gray School of Medicine, Winston-Salem, N.C.

X. J. Musacchia, Ph.D.

University of Louisville,

Kentucky

D. F. Proctor, M.D.

Johns Hopkins University,

Baltimore

M. J. Correia, Ph.D.

University of Texas,

Galveston

**Two areas of investigation.
Cardiovascular Deconditioning

Deconditioning of Antigravity Muscles

Effect of Weightlessness on

Fluid Physiology of the

Inner Ear

The Effects of Weightlessness

on Leukocyte Chemotaxis

Lower Limb Volume Measurements

Cardiovascular Deconditioning Correlated With Biochemical and Histological Indices of Cardiac Muscle Function

The Myotatic Reflex

Correlation of Macro- and Micro-circulatory Alterations During Weightlessness

Renal and Musculo-skeletal

Responses to Weightlessness

Respiratory Tract Particle Deposition and Clearance in the Space Environment

Anatomical and Electrophysiological studies of the Effects of Weightlessness on the Vestibular Apparatus 
H. A. Leon, Ph.D.

NASA Ames Research Center

Mountain View, Calif.

J. Migue1, Ph.D.

NASA Ames Research Center

M. D. Ross, Ph.D.

University of Michigan,

Ann Arbor

Augusto Cogoli, Ph.D. Laboratorium fur Biochemie, Zurich, Switzerland

M. J. Kluger, Ph.D.

University of Michigan,

Ann Arbor

r. - Yoong Hoh, Ph.D.

University of Sydney,

Australia

V. P. Popovic, D.SC.

Emory University,

Atlanta, Ga.

D. R. Young, Ph.D.

NASA Ames Research Center

**R. R. Martin, M.D.

Baylor College of Medicine, Houston

W. R. Loewenstein, Ph.D.

University of Miami,

Florida

A. R. Hargens, Ph.D.

University of California,

San Diego

J. W. Tremor, Ph.D.

NASA Ames Research Center

**Two areas of investigation.
The Influence of Space Flight on Red Cell production

Effects of Weightlessness on Drosophila Reproduction, Development and Aging

Effects of Space Travel on Mammalian Gravity Receptors

Lymphocyte Proliferation in Weightlessness

Febrile Responses During Space Flight

Skeletal Myosin Isoenzymes

Cardiovascular Adaptation to Decreased Gravity

Skeletal Changes During Space Flight

Effects of space Flight on Polymorphonuclear Leukocyte Function

Effects of space Flight on Intercellular Phenomena

Tissue-Fluid Shifts and Muscle Function During Weightlessness

The Effects of Weightlessness on the Development of Amphibian Eggs 
R. E. Herron, Ph.D.

Baylor College of Medicine, Houston

J. D. Fabricant, Ph.D. University of Texas, Galveston

D. E. Parker, Ph.D.

Miami University,

oxford, Ohio

J. S. Petrofsky, Ph.D.

Wright State University,

Dayton, Ohio

M. F. Reschke, Ph.D.

NASA Johnson Space Center,

Houston

A. D. LeBlanc, Ph.D.

Technology, Inc.

Houston

R. J. Gowen, Ph.D.

South Dakota School of Mines and Technology,

Rapid City

B. S. Criswell, Ph.D.

NASA Johnson Space Center

T. D. Stein, Ph.D.

University of Pennsylvania,

Philadelphia

K. M. Baldwin, Ph.D.

University of California,

Irvine

W. G. Walker, M.D.

Johns Hopkins University,

Baltimore

L. D. Montgomery, Ph.D.

LDM Associates

San Jose, Calif.
Biostereometric Analysis of Body Volume Changes During Sustained Weightlessness

Influence of space Flight on Cytogenics and Mutagenicity

- Behavioral and Physiological Changes as a Function of Postural Orientation/Motion Sickness in Space

Isometric Exercise Performance Under Zero-Gravity Conditions

Sensory Conflict as an Etiological Factor in space Sickness

Bone Growth and Repair

Segmental Fluid Shifts in Humans

The Effects of Space Flight on the Cellular Immune Response of Man

Protein Metabolism During Space Flight

Effect of Zero-Gravity Exposure on Biochemical and Metabolic Properties of Skeletal Muscle

Effects of Weightlessness on Diurnal Pattern on Renin, Aldosterone, and Electrolyte Excretion

Decreased Orthostatic Tolerance Accompanying Weightlessness 
**P.C. Johnson, M.D.

NASA Johnson Space Center, Houston

**P.C. Johnson, M.D.

NASA Johnson space Center

D. J. Horrigan, Jr.

NASA Johnson Space Center

C. S. Leach, Ph.D.

NASA Johnson Space Center

E. M. Holton, Ph.D.

NASA Ames Research Center,

Mountain View, Calif.

P. S. Cowings, Ph.D.

NASA Ames Research Center

S. Abraham, Ph.D.

Children's Hospital Medical

Center, Oakland, Calif.

J. B. West, Ph.D.

University of California,

San Diego

J. Oyama, Ph.D.

NASA Ames Research Center

J. T. Jackson

NASA Johnson Space Center

H. L. Stone, Ph.D.

University of Oklahoma,

Oklahoma City

H. Sandler, M.D.

NASA Ames Research Center

G. M. Reaven, M.D.

Veterans Administration Hospital

Palo Alto, Calif.
Countermeasures for Reducing

Post-Flight Orthostatic

Intolerance

Regulation of Blood Volume During Space Flight

The Effect of Null Gravity on Nitrogen Washout/Prevention of Decompression Sickness

Fluid - Electrolyte Regulation During space Flight

Effects of Space Flight on Bone Growth

Autogenic-feedback Training as a Preventive Method for Space Motion Sickness

Effects of Microgravity on Carbohydrate-Lipid

Interconversion

Pulmonary Function During Weightlessness

Mammalian Neonatal Development in Weightlessness

Static and Dynamic

Anthropometry

Mechanisms Underlying Fluid

Volume Shifts in Zero Gravity

Cardiovascular Effects of Weightlessness

Insulin Resistance in Space Flight/Effect of Exercise Training

**Two areas of investigation. 
G. L. Searle, Ph.D.

Veterans Administration Hospital San Francisco

M. C. Moore-Ede, M.D.

Harvard Medical School, Boston

A. H. Brown, Ph.D. University of Pennsylvania, Philadelphia

D. E. Philpott, Ph.D.

NASA Ames Research Center, Mountain View, Calif.

W. B. Severs, Ph.D. Milton S. Hershey Medical School Hershey, Pa.

C. A. Mitchell, Ph.D.

Purdue University,

West Lafayette, Ind.

J. W. Campbe11, Ph.D.

Rice University,

Houston

C. G. Blomquist, M.D. University of. Texas, Dallas

R. L. Popp, M.D.

Stanford University,

Stanford, Calif.

**S. Ellis, Ph.D.

NASA Ames Research Center

**S. Ellis, Ph.D.

NASA Ames Research Center

A. Bhattacharya, Ph.D. University of Kentucky, Lexington

**Two areas of investigation.
Insulin and Glucose Metabolism in Man

Fluid and Electrolyte Homeostasis

Gravitrophic Response of Plants

Inflight Monitoring of Retinal and Cerebral Circulation

Angiotension-Related Changes in Body Hydration

Influence of Mechanical Vibration on Plant Growth and Development Under Hypogravity Conditions

Adaptive Characterization of Enzymes of Nitrogen Metabolism

Cardiovascular Adaptation to Zero Gravity

Cardiovascular Effects of Weightlessness

Electron Microscopy, Electromyography, and Protease

Activity of Mammalian Muscles

Excretion of 3-Methyl

Histidine in Man During

Space Flight

Prevention of Cardiovascular Deconditioning 
**Nello Pace, Ph.D. University of California, Berkeley

D. M. Wiberg, Ph.D. University of California, Los Angeles

L. O. Green, Jr., Ph.D. NASA Ames Research Center, Mountain View, Calif.

E. M. Holton, Ph.D.

NASA Ames Research Center

C. A. Bowles, Ph.D. Hazelton Laboratories America, Inc.

Vienna, Va.

A. D. Krikorian, Ph.D. State University of New York, Stony Brook

R. E. Grindeland, Ph.D.

NASA Ames Research Center

M. Tavassoli, M.D.

Scripps Clinic and Research

Foundation,

La Jolla, Calif.

**Two areas of investigation.
Effects of Body Size on Mammalian Metabolism in Weightlessness

Pulmonary Blood Flow

Occulomotor Changes in Primates During Prolonged Weightlessness

Pre- and Post-Natal Development of Stress-Sensitive Skeletal Structures

Studies of the Immune system Under Weightless Conditions

The Effects of Hypogravity on Critical Cellular Events in Plant Development

Effects of Space Flight on Neuroendocrine Functions

Bone Marrow Repair During Weightlessness 